Portland State University

PDXScholar

$1-2014$

Heard on the Net: Oooops! They Did it Again; Old News, New News and Things to Watch in 2014

Jill Emery

Portland State University, jemery@pdx.edu

Follow this and additional works at: https://pdxscholar.library.pdx.edu/ulib_fac

Part of the Library and Information Science Commons

Let us know how access to this document benefits you.

Citation Details

Emery, J. Heard on the Net: Oooops! They Did it Again; Old News, New News and Things to Watch in 2014. The Charleston Advisor, Volume 15, Number 3, January 2014, pp. 62-62(1)

This Article is brought to you for free and open access. It has been accepted for inclusion in Library Faculty Publications and Presentations by an authorized administrator of PDXScholar. Please contact us if we can make this document more accessible: pdxscholar@pdx.edu. 
ADVISOR REPORTS FROM THE FIELD

Heard on the Net

\section{Oooops! They Did it Again; Old News, New News and Things to Watch in 2014}

doi:10.5260/chara.15.3.62

By Jill Emery (Collection Development Librarian, Portland State University)

$<$ jemery@pdx.edu>

$\mathrm{O}$ n 6 December, the news broke across various twitter streams that Elsevier had issued takedown notices of PDF articles of their content from Academia.edu. Here is a link to one of the letters sent by Academia.edu to Guy Leonard, a Bioinformatician: <http://svpow. files.wordpress.com/2013/12/oli5n9w.png $>$. There have been a myriad of reactions to this news from twitter, blogs, e-discussion lists, and The Chronicle of Higher Education. Charles Hamaker, in his post to libLicense on 8 December 2013, referred to Elsevier's issuing of the takedown notices as "an unforced error. "Hamaker's conclusion is that "Elsevier's unforced error may be more effective than any boycott." Many people have pointed out that Academia.edu is both a private company and working towards developing a profit-making service of shared content from faculty and researchers and they are also a competitor of Mendeley, which is also an academic social network. Tom Reller, VP and Head of Global Corporate Relations at Elsevier, issued a comment on the takedown notices on the ElsevierConnect Web site <http://www.elsevier.com/connect/a-comment-on-takedown-notices $>$. In his response, Mr. Reller, noted that the takedown notices were on the final versions of the published journal articles and lists the alternatives authors can take in regard to sharing their Elsevier publications. Many members of the library and information science community such as Deborah Lenares, Manager of Acquisitions and Resource Sharing at Wellesley College, note that this situation is actually a perfect example to use when LIS personnel engage with faculty about the copyright transfer agreements signed by authors with academic publishers and some of the limitations these agreements impose. It will be interesting to see if the fallout from the takedown notices will result in fewer submissions to Elsevier journals and if there will be a dip in impact factors over the next few years.

In slightly related news, at the Nobel prize award ceremonies in the first week of December 2013 , Randy Schekman, who won the Nobel prize in physiology or medicine, proclaimed his lab would no longer send research papers to the top-tier journals Nature, Cell, and Science per an article that appeared in the Guardian newspaper: <http://www. theguardian.com/science/2013/dec/09/nobel-winner-boycott-sciencejournals>. "Schekman said pressure to publish in 'luxury' journals encouraged researchers to cut corners and pursue trendy fields of science instead of doing more important work. The problem was exacerbated, he said, by editors who were not active scientists but professionals who favoured studies that were likely to make a splash." Editors from all three publications contributed to the article pointing out that they are all committed to serving the scientific and research community and arguing that they undertake to publish articles that pass through rigorous peer-review which bears a "real economic cost" and select papers for publication based on "scientific significance." Again, it will be interesting to watch to see what the fallout will be.

In the meantime, Sir Tim Berners-Lee led a call for the Web to be taken back by the ordinary people via the Financial Times <http:// blogs.ft.com/tech-blog/2013/12/tim-berners-lee-launches-campaignfor-ordinary-people-to-protect-the-web/> and announcing the launch of Web We Want campaign <https://webwewant.org/>. The campaign is an attempt to ensure that everyone throughout the world has access to an open and universal World Wide Web. One of their main goals for 2014 is to draft the Users Bill of Rights and have it adopted by governments throughout the world.

Knowledge Unlatched launched their pilot collection in October 2013 $<$ http://www.knowledgeunlatched.org $>$ as an attempt to provide free access to 28 titles from 13 recognized scholarly publishers. The goal is to have 200 libraries sign up to participate by the end of January 2014; if they succeed in getting more than 200 libraries involved then the cost will go down for each participating institution. The Wellcome Library has pledged their support of Knowledge Unlatched and a preservation agreement has been established with CLOCKSS to insure ongoing access to the pilot titles. This is a novel approach to trying to change the scholarship model for the academic monograph and it will definitely be worth tracking to see the outcomes of this pilot effort.

Curious to know whose work will be open to the public domain for the rest of the world in 2014? The Open Knowledge Foundation has created a Web site for a quick reference $<\mathrm{http}$ ://publicdomainreview. org/2013/12/10/class-of-2014/>. Starting on 1 January 2014, the works of Fats Waller, Beatrix Potter, George Washington Carver, and Nikola Telsa, just to name a few, will be released into the public domain. In case you didn't know, 1 January will be celebrated as Public Domain Day. Be sure to quote your favorite publicly available passage on this day! <http://www.publicdomainday.org/>

Lastly, according to readwrite, 2014 will be the year that smartphones will surpass the number of PCs <http://readwrite.com/2013/12/10/ smartphone-pcs-install-base-2014\#awesm $=\sim$ opFXmKLdoYZLBe $>$. This takeover signifies that the notion of mobility as a trend ceases to be something different from any other form of computing. The day of ubiquity is fast approaching and either you're ready for it or not. 